Jon Lekven (f. 1941) er leder av REK Vest. Forfatter har fylt ut ICMJE-skjemaet og oppgir ingen interessekonflikter.

Sven Erik Gisvold (f. 1944) er leder av REK MidtNorge.

Forfatter har fylt ut ICMJE-skjemaet og oppgir ingen interessekonflikter.

Jørgen Hardang (f. 1945) er komitésekretær i REK Sørøst A.

Forfatter har fylt ut ICMJE-skjemaet og oppgir ingen interessekonflikter.
Litteratur

1. Lov om medisinsk og helsefaglig forskning. www.lovdata.no/all/hl-20080620-044.html (2.10.2012).

2. Veileder til lov 20. juni 2008 nr. 44 om medisinsk og helsefaglig forskning. www.regjeringen.no/ upload/HOD/HRA/Veileder $\% 20$ til\%20 helseforskningsloven.pdf (2.10.2012).

3. Kjennetegn som REK bør observere i spørsmål om kvalitetssikring vs. fremleggingspliktige prosjekter. FREK 2.12.2011. http://helseforskning. etikkom.no/ikbViewer/Content/275633/ Kvalitetssikring\%20vs\%20framleggingspliktig\% 20prosjekt\%20FREK\%20des\%202011.pdf (26.9.2012).
4. Framleggingsvurdering. http://helseforskning. etikkom.no/ikbViewer/page/frister/ forskningsprosjekt?p_dim=34769 (2.10.2012).

Mottatt 20.9. 2012, første revisjon innsendt 17.10. 2012, godkjent 18.10. 2012. Medisinsk redaktør Siri Lunde.

Publisert først på nett 2.11. 2012

\title{
Forskes det for mye her i landet?
}

\author{
Vi mener den store oppmerksomheten omkring doktorgraden som det viktigste målet for vitenskapelig \\ virksomhet i Norge er en blindvei. Denne strategien vektlegger kvantitet fremfor kvalitet og reduserer \\ muligheten for å kombinere klinisk arbeid med forskning, noe som er vanlig i mange andre land.
}

Mange vil vel mene at professorer som stiller et slikt spørsmål burde finne seg noe annet å gjøre. På redaksjonelt hold i Tidsskriftet har det imidlertid vært pekt på at det nå publiseres altfor mange artikler som ikke holder tilstrekkelig vitenskapelig kvalitet (1). Representanter for andre fagområder har også gitt uttrykk for liknende synspunkter (2). Etter vårt syn må slike betraktninger ses på bakgrunn av store svakheter og mangler ved organiseringen av norsk forskning. Dette gjelder både omfang, fordeling av midlene - for mye til lønn og for lite til driftsmidler og utstyr - samt organisering, med altfor stor vekt på doktorgradssporet, i hvert fall innen fagområdet medisin, som er det området vi kjenner best til. Den evalueringen av medisinsk forskning som Norges forskningsråd nylig gjennomførte har også pekt på disse problemstillingene (3).

Universitetssykehusene og de medisinske fakulteter konkurrerer hvert år om å frembringe flest publikasjoner og doktorgrader. En doktorgrad (ph.d.-grad) gir status for kandidaten og veilederne, og antallet doktorgrader gir status til institutt, fakultet og universitet. Ved ansettelse i professorater vektes tilsynelatende veiledning av doktorander høyere enn annen akademisk, undervisningsmessig og forskningsmessig meritt.

Det argumenteres ofte med at målet for doktorgradsutdanningen er å gi kandidaten innføring i forskningsteori og dermed økt kompetanse til å vurdere andres forskningsresultater samt til selv å initiere videre forskning. Men gitt volumet av ressursene som investeres, både fra samfunnets og kandidatens side, synes det rimelig å spørre om doktorandene faktisk initierer egen forskning og om forskningsteori og kritisk leseevne kanskje kunne læres like godt på andre måter og med bedre ressursbruk.

\section{Trengs det $\mathbf{4 0 0}$ eller $\mathbf{4 0}$ bakere?}

I 2011 ble det avlagt 1327 doktorgrader i Norge, herav 396 ved de medisinske fakultetene, dvs. en økning på $70 \%$ fra 2007 (4). Ifølge rektor Ole Petter Ottersen ble det avlagt 160 doktorgrader ved Det medisinske fakultet i Oslo i første halvår i 2012, noe som er ny rekord (5). Dette blir mer enn én disputas per dag. Samtidig har

\section{«Svært få leger som tar doktorgraden fortsetter en viten- skapelig karriere»}

undersøkelser de siste årene vist at svært få leger som tar doktorgraden fortsetter en vitenskapelig karriere. Dette kan skyldes flere forhold, bl.a. manglende stillinger på neste karrierenivå, ved at forholdet mellom doktorgradsstipendiater og stillinger som postdoktor eller førsteamanuensis er omtrent 10:1 her i landet. Dette tilsier at de fleste stipendiater ikke har noen mulighet til å komme videre i en forskerkarriere. Denne situasjonen har bl.a. vært drøftet på årskonferansen for Leger i vitenskapelige stillinger (LVS) både i Oslo i 2011 og sist i Tromsø i 2012, der temaet for konferansen var Hvor ble det av legeforskeren etter avsluttet ph.d.-grad? (Dag Bratlid, personlig meddelelse). De som har forsket innen laboratoriefag og eksperimentell medisin har dessuten få muligheter til å videreføre sin forskning hvis de går tilbake til en klinisk stilling.

Man kan derfor spørre seg - med referanse til et fagområde en av oss kjenner godt - hvor fornuftig det er å utdanne 400 bakere dersom det bare er 40 som kan få jobb som baker? Det kan kanskje være nyttig å være utdannet baker for å selge brød i butikken eller kjøre brødbil, men er et svennebrev en effektiv investering av tid og ressurser for å utføre slike jobber? Er den betydningen som tillegges doktorgraden den beste strategien for å gi leger akademisk kompetanse og stimulere til forskning? Lønn til de mange doktorgradskandidatene beslaglegger nå så store deler av instituttenes budsjetter at det kan gå utover andre områder. Norske universiteter synes å bruke en større del av sine budsjetter på lønnsmidler enn universiteter i mange andre land (6).

\section{Vanskelig å kombinere klinisk stilling og forskning}

Forskning er en av hovedoppgavene i sykehus, på linje med diagnostikk og pasientbehandling. Legenes tjenesteplaner inneholder fordypningstid til forskning og fagutvikling som imidlertid er dårlig organisert og ofte blir inndratt ved sykdom og 
annet fravær. Samtidig er leger ved mange avdelinger doktorgradsstipendiater ved eksterne institusjoner og kan fordype seg i forskning på heltid. Dette forsterker inntrykket av at forskning ikke lar seg kombinere med en klinisk stilling.

På denne bakgrunnen har vi mange ganger undret oss over hvorfor ikke de betydelige forskningsmidlene som de regionale helseforetakene nå disponerer, fremfor å finansiere doktorgradsstipendiater ved universitetene ikke heller brukes til å kjøpe fri leger fra klinisk avdelingsarbeid slik at de i større grad kan kombinere klinisk arbeid og forskning uten at målet er en doktorgrad?

\section{Lege med doktorgrad -}

Vi har regelmessig kontakt med utenlandske kolleger som er blant verdens fremste innen sine fagområder. Få av disse kan smykke seg med en doktorgradstittel. De har arbeidet med sin forskning parallelt med klinisk arbeid på en avdeling som er tilrettelagt for dette, noe som synes å ha lite fokus i Norge. For disse kollegene synes forskning å være en naturlig del av den kliniske virksomheten, ikke et middel til å oppnå en tittel.

Dette kan bl.a. illustreres ved at blant de legene som er medlemmer av redaksjons- komiteene i JAMA og New England

Journal of Medicine eller er bidragsytere i større lærebøker som Harrison's Principles of internal medicine, er det bare et fătall som har doktorgrad. I USA er det riktignok nå økt vekt på «combined degree programs», der man samtidig blir ph.d. og MD. Disse kandidatene er imidlertid nærmest garantert en kombinert stilling og sjenerøse startbevilgninger for å bygge en karriere innen et definert fagområde (professor David Stevenson, Stanford, personlig meddelelse).

Kanskje vi også skulle gjøre noe liknende med utvalgte stipendiater? Doktorgrad som et isolert forskningsmål for medisinere synes i stor grad å være et skandinavisk og nordeuropeisk fenomen.

\section{Dag Bratlid}

dag.bratlid@ntnu.no

Thor Willy Ruud Hansen

Dag Bratlid (f. 1944) er professor i pediatri ved Norges teknisk-naturvitenskapelige universitet og overlege ved Nyfødtintensivavdelingen ved Barne- og ungdomsklinikken ved St. Olavs hospital.

Forfatter har fylt ut ICMJE-skjemaet og oppgir ingen interessekonflikter.
Thor Willy Ruud Hansen (f. 1946) er professor i pediatri ved Universitetet i Oslo og overlege ved Nyfødtavdelingen, Kvinne- og barneklinikken, Oslo universitetssykehus.

Forfatter har fylt ut ICMJE-skjemaet og oppgir ingen interessekonflikter.

\section{Litteratur}

1. Hem E. For mange tidsskrifter - for lite god forskning. Tidsskr Nor Legeforen 2011; 131: 1871.

2. Hessen vil ha mindre forskning ved høgskulane. Uniforum 16.2.2012.

3. Evaluation of biology, medicine and health research in Norway (2011). Report of the principal evaluation committee. Oslo: The Research Council of Norway, 2011.

4. Rekordvekst i doktorgrader. Aftenposten 20.2.2012.

5. Ny doktorrekord i Oslo. Aftenposten 23.5.2012.

6. OEDC. Education at a glance 2012: OECD indicators. www. oecd.org/edu/eag2012.htm (22.10.2012).

Mottatt 20.6. 2012, første revisjon innsendt 20.8 . 2012, godkjent 23.10. 2012. Medisinsk redaktør Petter Gjersvik.

Publisert først på nett 2.11. 2012 